ВІСНИК

ОДЕСЬКОГО НАЦІОНАЛЬНОГО

МОРСЬКОГО УНІВЕРСИТЕТУ
HERALD

OF THE ODESSA NATIONAL

MARITIME UNIVERSITY

№ 3 (63), 2020

УДК 629.5:624.04

DOI 10.47049/2226-1893-2020-3-76-105

\title{
МОДЕЛІ ТА МЕТОДИ ДОСЛІДЖЕННЯ СУДНОВИХ БАЛОК ЗІ ЗЛАМОМ СТІНКИ ТА ПОЯСКУ
}

В.М. Соков

науковий співробітник, асистент кафедри БМ та ККК valera.sokov@gmail.com, ORCID: 0000-0003-3933-879X

\section{Л.I. Коростильов}

д.т.н., проф., в.о. зав. кафедри БМ та ККК

Наиіональний університет кораблебудування імені адмірала Макарова, Украӥна, м. Миколаӥв

Анотація. У роботі представлено обтрунтування вибору методів розрахунку досліджуваної типової суднової балки зі зламом стінки та пояску шляхом аналізу різних моделей, щь застосовуються для розрахунку тонкостінних конструкиій. Проаналізовано теорії розрахунку тонкостінних стержнів 3 метою можливості їх застосування до досліджуваної балки та показана неможливість застосування ијих теорій по причині складної депланаиії пояску в місиях його зламу та на похилій частині суднової балки. Доведено необхідність застосування по крайній мірі оболонкових, а краще об'ємних моделей теорії пружності. Розглянута проблема ефективної ширини вільного пояску викликаної зсувною затримкою та місчевою втратою стійкості. Показано необхідність врахування депланаџії пояску при визначенні ефективної ширини. Зроблено огляд публікацій присвячених зсувній затримщі $i$ ефективній ширині та виявлені основні тенденції в цььому напрямі. Коротко оглянуті основні методи розрахунку стійкості. Захоплені проблеми зварного шва $і$ оптимального проекту-вання тонкостінних зварних балок стосовно досліджуваної балки.

Ключові слова: тонкостінна балка, балка зі зламом осі, балка зі зламом стінки і пояску, непризматична балка, I- , H- , T- переріз, двотавр, депланачія.

УДК 629.5:624.04

DOI 10.47049/2226-1893-2020-3-76-105

\section{МОДЕЛИ И МЕТОДЫ ИССЛЕДОВАНИЯ СУДОВЫХ БАЛОК С ИЗЛОМОМ СТЕНКИ И ПОЯСКА}

В.Н. Соков

научный сотрудник, ассистент кафедры СМ и ККК

Л.И. Коростылев

д.т.н., проф., и.о. зав. кафедри СМ и ККК

Национальный университет кораблестроения

имени адмирала Макарова, Украина, г. Николаев 
() Соков В.М., Коростильов Л.І., 2020

Аннотация. В работе представлено обоснование выбора методов расчета исследуемой типовой судновой балки с изломом стенки и пояска путем анализа различных моделей, которые применяются для расчета тонкостенных конструкиий. Проанализированы теории расчета тонкостенных стержней с иелью возможности их применения к исследуемой балке и показана невозможность применения этих теорий по причине сложной депланации пояска в местах его излома и на наклонной части судновой балки. Доказано необходимость применения по крайней мере оболочечных, а лучше объемных моделей теории упругости. Рассмотрена проблема эффективной ширины свободного пояска вызванной сдвиговой задержкой и местной потерей устойчивости. Показана необходимость учета депланации пояска при определении эффективной ширины. Произведен обзор публикаций посвященных сдвиговой задержке и эффективной ширине и выявлены основные тендениии в этом направлении. Коротко осмотрены основные методы расчета устойчивости. Охвачены проблемы сварного шва и оптимального проектирования тонкостенных сварных балок касательно исследуемой балки.

Ключевые слова: тонкостенная балка, балка с изломом оси, балка с изломом стенки и пояска, непризматическая балка, I- , H- , T- сечения, двутавр, депланация.

UDC 629.5:624.04

DOI 10.47049/2226-1893-2020-3-76-105

\title{
MODELS AND METHODS OF ANALYSIS OF SHIP BEAMS WITH BREAKS OF WEBS AND GIRDLE
}

\author{
V.M. Sokov \\ researcher, assistant of the dep. SM and CS, \\ valera.sokov@gmail.com, ORCID: 0000-0003-3933-879X \\ L.I. Korostylov \\ Dr.Tech.Sc., Professor, acting the head of the dep. SM and CS \\ Admiral Makarov National University of Shipbuilding, Ukraine, Mykolaiv
}

\begin{abstract}
In this paper there is presented the justification of the choice of methods of calculation of investigated typical ship beam with break of a web and girdle by the way of analysis of different models which are used for calculation of thin-walled constructions. There are theories are analyzed of calculation of thin-walled rods with the aim of possibility of its application to the mentioned beam. There were reviewed such widely used theories as Vlasov's, Umanskiy and Slivker's theories, Generalized Beam Theory (GBT), Finite Strip Method (FSM). Comparing strain-stress state obtained for the series of variants for the investigated beam by the solution of the volume problem of the theory of elasticity using finite element method with the strain-
\end{abstract}


stress state which could be obtained applying said thin-walled theories there is made the conclusion about impossibility of application of mentioned thinwalled theories by the reason of complex warping of a girdle in places of its break and on the inclined part of steep ascent of the ship beam. Mentioned theories were developed originally for prismatic rods. Vlasov's, Umanskiy and Slivker's theories can be carefully applied for nonprismatic beams with a faired change of a gradient of a beam cross section which is not provided in places of break of a girdle of the beam investigated. The assumption of immutability of a cross section in frames of just said theories don't work in places of breaks of a girdle due to complex warping there. There is proved the necessity of application of at least shell models but it is better volume models of the theory of elasticity, because the real distribution of stresses in the beam investigated is a little bit more complicated that shell theories propose. The problem of the effective width of a free girdle caused by a shear lag and local buckling is discussed. It was shown that a warping of a free girdle in places of its break has to be taken into consideration when define effective width. There is short review of publications dedicated to a shear lag and effective width is presented and tendencies are analyzed. There are shortly reviewed basic methods of calculation of three general kinds of the thin-walled rods stability: global, local and distortional. There are problems are mentioned of a weld joint and optimal design of thin-walled beams relatively investigated beam. It was shown that a weld joint have to be taking into account at optimal design.

Keywords: thin-walled beam, beam with broken axis, beam with break of a web and girdle, nonprismatic beam, I-, H-, T- sections, joist, warping/deplanation.

Постановка задачі. У складі корпусу судна доволі часто зустрічаються балки зі зламом стінки та пояску, показаної на рис. 1.

Ця балка нижньою кромкою кріпиться до настилу, а до ламаної кромки кріпиться вільний поясок для підвищення осьового моменту опору, що призводить до підвищення міцності і жорсткості при згині, для забезпечення стійкості при дії стискуючих осьових сил та плоскої форми згину. Металеві балки такого типу $€$ зварними. $€$ різні способи виготовлення таких балок, що відрізняються зокрема схемою зварювання та сумарною довжиною зварних швів. Дана балка відноситься до тонкостінних непризматичних стержнів відкритого профілю 3 симетричним перерізом відносно однієї 3 площин, або просто 3 односиметричним поперечним перерізом.

Ця балка/вузол є об'єктом дослідження іiі напружено-деформованого стану (НДС) 3 метою створення по можливості простих інженерних методик іiї проектування при відносно широкому варіюванні геометричних параметрів при пружному та пружно-пластичному деформуванні в тому числі з врахуванням впливу зварного шва. 


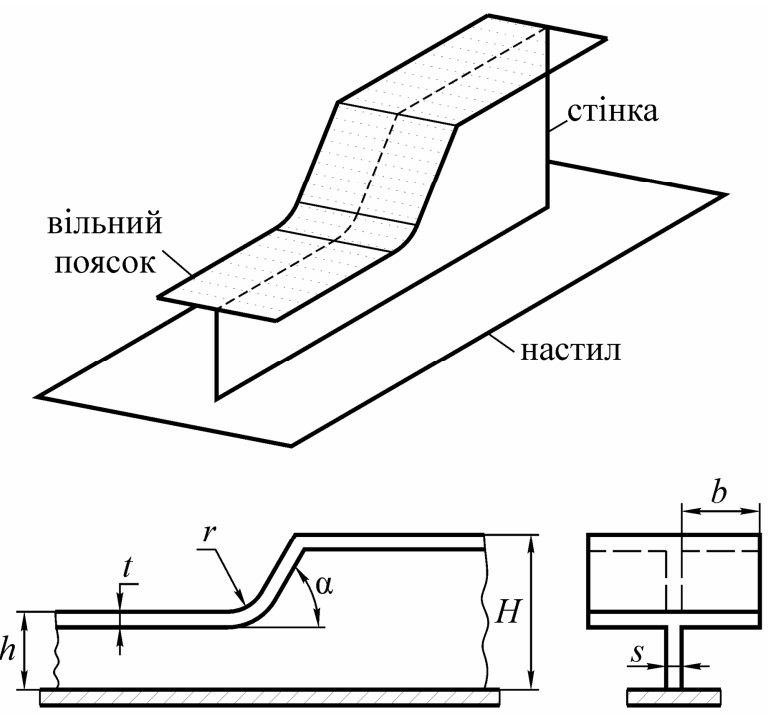

Рис. 1. Загальний вигляд досліджуваної балки зі зламом стінки і пояску

Мета дослідження. Проаналізувати останні досягнення та напрями в розрахунках тонкостінних стержнів та стержневих конструкцій в цілому, виявити основні тенденції в моделях та методах дослідження НДС та проектування тонкостінних конструкцій. На основі аналізу методів та моделей розрахунку тонкостінних стержнів та конструкцій зробити висновок щодо можливості їх застосування до досліджуваної балки на рис. 1.

Методи, об'єкт та предмет дослідження. Об'єкт дослідження представляє собою балку зі зламом стінки і пояску, представлену на рис. 1. Предметом дослідження $є$ напружено-деформований стан такої балки в цілому, а також окремих їі частин, таких як вільний поясок та зварний шов при пружному та пружно-пластичному деформуванні. Методом дослідження $є$ метод скінченних елементів (МСЕ).

Основний матеріал. Досліджуваний вузол, що представляє собою обговорювану балку зі зламом стінки і пояску, представлену на рис. 1 доволі рідко зустрічається в літературі в чистому вигляді. В іноземній літературі двотавровий переріз іноді позначається як I- або рідше Нпереріз, тавровий переріз як Т-переріз (I-, H-, Т-переріз). Напрями дослідження тонкостінних стержнів і конструкцій дуже різноманітні. В основному розглядаються призматичні та рідше конусоподібні балки. Непризматичні балки, поперечний переріз яких змінюється за більш складним законом, дуже рідко зустрічаються в літературі і такі роботи носять сугубо теоретичний характер без інженерного застосування. Так в доповіді конференції [16] було озвучено критичні питання, що виникають 
при розрахунках непризматичних тонкостінних балок довільної геометрії поперечного перерізу. Було показано, що дійсний розподіл дотичних напружень в цих балках грунтовно відрізняється від того, що має місце в призматичних балках, навіть в рамках спрощених моделей. Більш того ця різниця не може бути знехтувана навіть для балок, що сходять на конус, (див. похилу частину балки на рис. 1.), що зводить нанівець в загальному випадку можливість застосування наближених теорій типу Власова та ін. для непризматичних стержнів в загальному випадку, так як рівняння цих теорій отримані для призматичних балок.

Аналіз нормативних офіційних документів, таких як документи класифікаційних спільнот в області суднобудування [1]-[5] і цивільного будівництва [6]-[10], деяких недавніх монографій [11]-[12], присвячених тонкостінним конструкціям, показав, що наразі немає достатніх та систематичних методик проектування досліджуваного вузла на рис. 1. Ці методики обмежуються лише простими рекомендаціями у вузькому діапазоні зміни геометричних параметрів або для конкретних варіантів без систематичних узагальнень, які стосуються лише пружного деформування вузла, не кажучи вже про роботу в пружно-пластичній області. В роботах [13]- [15] представлені результати по дослідженню НДС саме балки, зображеної на рис. 1. Проте, дослідження виконані в [15], де представлені результати наближених розрахунків НДС, були виконані із застосуванням наближених методів та експериментальних досліджень методом електротензометрування та оптичного, що було пов'язано з обчислювальними проблемами того часу. В роботах [13], [15] представлені залежності для ефективної ширини вільного пояску, викликаної зсувною затримкою, лише для перерізу розташованого в місці переходу від меншої висоти стінки до більшої. Ці формули були отримані шляхом обробки експериментальних даних отриманих методом електротензоментрування, при розміщенні тензорезисторів на зовнішній стороні вільного пояску.

Для досліджуваної балки зі зламом стінки і пояску, зображеної на рис. 1 була створена об'ємна скінченно-елементна модель залежна від геометричних параметрів, що дозволяє вирішувати об'ємну задачу теорії пружності. Скінченні елементи (СЕ) представляють собою тетраедри 3 лінійною (тетраедр 3 4-ма вузлами), квадратичною (тетраедр 3 10-ма вузлами) та кубічною (тетраедр 3 20-ма вузлами) апроксимацією переміщень. Для серії варіантів об'ємних моделей досліджуваної балки були проведені розрахунки НДС з використанням вищезгаданих СЕ.

Як показують попередні розрахунки НДС, виконаних на об'ємних моделях досліджуваної балки методом скінченних елементів (МСЕ) для окремих варіантів геометрії, напружений стан верхньої і нижньої сторін та серединного шару вільного пояску відрізняються між собою і теоретично не можуть бути достовірно обчислені навіть за допомогою оболонкових/пластинчастих скінченних елементів (СЕ), т. я. дійсне 
розподілення нормальних напружень по товщині пояску в загальному випадку нелінійне, що дасть різні значення приведеної ширини, розглядаючи відповідно зовнішню, внутрішню сторону та серединний шар пояску у вищезгаданому перерізі. Залишається відкритим питання про залежність ефективної ширини від координати вздовж похилої ділянки. Нерівномірність розподілення нормальних напружень на похилій ділянці не тільки по ширині, а і по товщині пояску створює труднощі для визначення його ефективної ширини, тому що класична методика, що грунтується на плоскій задачі теорії пружності, передбачає рівномірний розподіл нормальних напружень саме по товщині пояску. На похилій ділянці має місце доволі складна депланація вільного пояску, яка захоплює в тому числі і зони пояска призматичних частин балки, що прилягають безпосередньо до похилої частини. В місцях депланації має місце об'ємний напружений стан, що формально унеможливлює застосування класичної методики визначення приведеної ширини, так як в місці депланації не реалізовується в повній мірі плоский напружений стан.

На основі аналізу літератури та публікацій в рамках сформульованої мети дослідження можна виділити наступні основні задачі, які потрібно проаналізувати та вирішити для досліджуваної балки зі зламом стінки та пояску:

1) дослідження НДС стінки без пояску, аналіз концентраторів напружень та оптимальне проектування стінки 3 оглядом на концентрацію напружень;

2) моделі та методи розрахунку міцності тонкостінних стержнів в цілому та можливість їх застосування до досліджуваної балки зі зламом стінки і пояску;

3) розрахунок загальної, місцевої та викривленої (distortional buckling) стійкості тонкостінних стержнів;

4) визначення ефективної/приведеної ширини пояску, викликаною зсувною затримкою та втратою стійкості пояску;

5) розрахунки при динамічних навантаженнях, ударі та вібрації;

6) дослідження впливу зварного шва на загальний НДС конструкції;

7) дослідження втомної міцності зварних швів;

8) оптимальне проектування тонкостінних стержнів.

Вищенаведені дослідження потрібно проводити для пружного i для пружно-пластичного деформування.

Аналіз п. 1. Дослідження НДС стінки без пояску, аналіз концентраторів напружень та оптимальне проектування стінки 3 оглядом на концентрацію напружень. Результати досліджень 1-го напряму, присвяченому стінці балки на рис. 1 без пояску, були опубліковані в роботах [17]-[19], де вирішувалася плоска задача теорії пружності, застосовуючи МСЕ 3 6-ма вузлами і квадратичною 
апроксимацією переміщень. В [17] представлені залежності для коефіцієнту концентрації при осьо-вому навантаженні стінки, а в [18] залежності для коефіцієнту концентрації при згинальних навантаженнях. У [19] представлені методики оптимального проектування стінки 3 оглядкою на коефіцієнт концентрації напружень як при осьових так і при згинальних навантаженнях. В публікаціях [17]-[19] розглядалася тільки пружна робота стінки.

Для тонкостінних стержнів розрахунок міцності і стійкості як правило $\epsilon$ взаємопов'язаним. Тому що при навантаженнях, які викликають поперечний згин може виникнути втрата стійкості. Тому розподіл методів дослідження НДС тонкостінних стержнів на методи дослідження міцності і стійкості є дещо умовним.

Аналіз п. 2. Моделі та методи розрахунку міцності тонкостінних стержнів в цілому та можливість їх застосування до досліджуваної балки зі зламом стінки i пояску. Опрацювання літератури та публікацій по методам розрахунку тонкостінних стержнів був проведений в ключі можливості застосування того чи іншого методу для розрахунку балки зі зламом стінки та пояску на рис. 1. для проведення серійних розрахунків із забезпеченням достатньої точності. Досліджувана балка може бути представлена такими моделями, як тонкостінний стержень, оболонкова або пластинчата модель, тривимірне масивне тіло. Тому спочатку будуть проаналізовані теорії розрахунку тонкостінних стержнів, потім проаналізовано можливість застосування оболонкової/пластинчастої моделі стосовно досліджуваної балки.

Шляхом порівняння НДС обчисленого для ряду моделей досліджуваної балки (при вирішенні об'ємної задачі теорії пружності із застосуванням МСЕ) 3 НДС, які отримуються при використанні наближених теорій розрахунку тонкостінних стержнів були зроблені висновки щодо можливості застосування тих чи інших теорій розрахунку тонкостінних стержнів стосовно досліджуваної балки.

Огляд публікацій, присвячених тонкостінним стержням показав, що історично сформувалися в основному два напрями практичних методів розрахунку НДС таких стержнів: методи розрахунку тонкостінних стержнів відкритого профілю, методи розрахунку тонкостінних стержнів замкнутого профілю [20]. Стержні відкритого профілю розраховуються в переважній більшості з використанням теорії Власова В.3. [21], модифікованих та похідних теорій від неї, рідше прямого методу сил [22], методу скінченних смуг [23], узагальненої балочної теорії Шардта [24] та ін. Стержні замкнутого профілю розраховуються, використовуючи теорію Уманського А.А. [25] та теорій розвинених з неї. Специфіка розрахунку тонкостінних конструкцій така, що міцність і стійкість розглядаються нерозривно один від одного, тому що при навантаженнях, які повинні б були викликати згин виникає втрата 
стійкості та ін. Тому більшість досліджень присвячених тонкостінним стержням стосуються власне питання стійкості насамперед.

3 точки зору чисельної реалізації недоліком теорії Власова $\epsilon$ залежність міри депланації стержня від кута закручування. Також однією 3 гіпотез цієї теорії $є$ відсутність деформацій зсуву серединної поверхні стержня, що в декотрих задачах призводить до виникнення великих неточностей. Тому ряд авторів пропонували різні моделі тонкостінних стержнів, де тим чи іншим чином враховувався зсув. Проте широкого застосування ці теорії не отримали у зв'язку зі своєю складністю у плані реалізації їх уніфікованими чисельними методами, такими як наприклад MCE [29].

Прямий метод сил був розроблений в США і наряду з методом ефективної ширини застосовується при проектуванні тонкостінних конструкцій в Північній Америці, Новій Зеландії, Бразилії, та інших країнах. Метод ефективної ширини представляє собою редукцію окремих пластинчастих елементів, що входять до складу поперечного перерізу, при втраті стійкості окремими з них. Прямий метод сил не використовує поняття ефективної ширини і не потребує ітеративного процесу для визначення ефективних властивостей. Замість цього метод використовує рішення втрати стійкості використовуючи геометричні характеристики поперечного перерізу в цілому, для того, щоб визначити міцність стержня в рамках трьох ключових станів: загальної стійкості, місцевої стійкості (включаючи взаємодію з загальною стійкістю) та викривленої стійкості.

В публікації [26] ведеться мова про застосування прямого методу сил стосовно проектування тонкостінних стержнів, i тут же вказані основні переваги та недоліки цього методу. Наведемо деякі головні його недоліки. В прямому методі сил немає врахування зсуву та викривлень стінки та ін. Цей метод може дати неприйнятні результати у випадку наявності у складі поперечного перерізу дуже тонких складових елементів; зсув нейтральної осі ігнорується; також метод $є$ емпіричним, налаштованим лише для роботи 3 поперечними перерізами, попередньо дос-лідженими перед цим. Прямий метод сил забезпечує аналіз пружної втрати стійкості для всього поперечного перерізу, а не для ізольованих елементів. Рівняння для розрахунку міцності в цьому методі є емпіричними, проте серія досліджених поперечних перерізів $є$ доволі великою.

Однією з головних переваг прямого методу сил $\epsilon$ швидка оцінка міцності, що $\epsilon$ зручним при проектуванні складних конструкцій складених з великої кількості тонкостінних і переважно призматичних стержнів різного профілю. Цей метод швидше створений для масового використання в промисловості, ніж для проведення наукових досліджень.

Суть методу скінченних смуг полягає в тому, що тонкостінне видовжене тіло розбивається вздовж на ряд смуг, які взаємодіють між собою. Цей метод, що був розроблений в 1968 році, має схожі риси 3 методом скінченних елементів, поступаючись останньому в точності, 
проте для видовжених тіл використання цього методу може бути більш ефективним [23] з точки зору використання обчислювальних ресурсів. На базі методу скінченних смуг розроблені модифікації. Проте він має свої недоліки. По-перше метод скінченних смуг часто зазнає невдачі при однозначному визначенні форм втрати стійкості при розрахунку викривленої та місцевої стійкості. По-друге нещодавно розроблений так званий обмежений метод скінченних смуг, який дає однозначні результати при обчисленні викривленої та місцевої стійкості страждає від власної обмеженості, тому що $(a)$ він не досягає такого самого рішення як класичний метод скінченних смуг для одних і тих же випадків, а також обмежений метод не враховує скруглені кути у моделі поперечного перерізу. По-третє метод скінченних смуг розроблявся для призматичних балок і дає прийнятні результати саме для них. Відомий прикладний програмний пакет CUFSM для розрахунку методом скінченних смуг.

В роботі [27] представлено порівняння результатів отриманих 3 використанням методу скінченних смуг та обмеженого методу скінченних смуг реалізованих в контексті прямого методу сил.

Узагальнена балочна теорія розроблена на базі технічної теорії згину балок (ТТЗБ) в 1966 році, дозволяє враховувати викривлення, деформування і депланації поперечних перерізів у поперечному напрямі, на відміну від теорії Власова, де поперечний переріз вважається абсолютно жорстким тілом, шляхом введення так званих деформаційних форм/мод поперечного перерізу. Ця теорія дає хороші результати для тонкостінних призматичних стержнів відкритого профілю i дозволяє проводити розрахунки як міцності так і стійкості. Широкого застосування не отримала у зв'язку зі своєю специфічністю. Наразі не існує офіційного програмного забезпечення, яке реалізує цю теорію, за винятком деяких аматорських. Цю теорію переважно розвиває Camotim D. та інші дослідники. У праці [28] представлено скінченно-елементну модель тонкостінного стержня саме на базі узагальненої балочної теорії.

Як вже було зазначено вище, теорії розрахунку тонкостінних стержнів розроблялися i розвивалися незалежно для відкритих i замкнутих профілів, що створювало незручності з точки зору уніфікації розра-хунків тонкостінних стержнів. В 2005-му році Слівкером В.І. була роз-роблена універсальна напівзсувна (полусдвиговая) [29] теорія тонкостінних стержнів, яка придатна для розрахунку стержнів відкритого, замкнутого та комбінованого профілів (відкрито-замкнутого та багатоконтурного), що поклало край незалежним дослідженням відкритих та замкнутих контурів, хоча схожі теорії, придатні одночасно для розрахунку відкритих і замкнутих профілів розроблялися і раніше, проте не отримали розповсюдження по різним причинам. Згадана теорія Сліврека є складнішою, проте точнішою у порівнянні з теорією Власова $\mathrm{i}$ Уманського. В дисертації [30] на базі чисельної реалізації теорії Слівкера були проведені декотрі дослідження тонкостінних конструкцій. 
Серед публікацій присвячених тонкостінним стержням слід виділити працю [31], де представлено аналітичний огляд i аналіз публікацій до 2015-2018 рр., що розкривають тему розрахунку сталевих тонкостінних конструкцій. В цій роботі детально освітлені основні принципи фундаментальних теорій розрахунку тонкостінних стержнів: теорії Власова В.З., Уманського А.А., Слівкера В.І., представлені табличні порівняння елементів деформування для цих теорій, розглянуті спільні і відмінні риси, переваги та недоліки. В цій публікації розглянуті праці присвячені реалізації розроблених теорій для розрахунку тонкостінних стержнів в рамках MCE.

У [32] підтверджено високу узгодженість результатів розрахунку НДС стержня відкритого профілю, розрахованого за моделями Власова $\mathrm{i}$ Слівкера.

У джерелах [20], [31] представлено також коротку історію розвитку теорій та методів розрахунку тонкостінних стержнів.

Проаналізуємо спочатку теорії розрахунку тонкостінних стержнів Власова (і заодно Уманського) в плані можливості їх застосування до розрахунку досліджуваної балки зі зламом стінки і пояску на рис. 1. В наближених теоріях Власова i Уманського $\epsilon$ спільні гіпотези, які визначають границі застосування вказаних теорій, при невиконанні яких похибка обчислень буде перевищувати допустиму величину. До цих гіпотез належать:

1. Поперечний переріз профілю тонкостінного стержня залишається незмінним у своїй площині як до так і після деформування, тобто $є$ недеформівним в поперечному напрямі. Поперечний переріз приймається абсолютно жорстким тілом, яке може рухатися і обертатися. По відношенню до досліджуваної балки на рис. 1 ця гіпотеза не виконується по причині складної депланації вільного пояску саме у поперечному напрямі на похилій частині балки, що захоплює також $\mathrm{i}$ частини пояска прилягаючих до неї призматичних частин. Депланація нагадує махання крилами птиці.

2. Нормальні напруження у поздовжньому напрямі стержня вважаються рівномірно розподіленими по товщині стінки, таким чином контур тонкостінного стержня є безмоментним. В областях переходу призматичних частин стержня досліджуваної балки до похилої частини має місце місцевий згин полотна пояску, так що нормальні напруження у поздовжньому напрямі змінюють знак. Проте на віддалені від вказаних областей переходу розподілення нормальних напружень стає більш рівномірним по товщині, але різниця між верхнім та нижнім шаром стінки стає більш відчутною при збільшенні товщини пояску.

3. Поздовжні шари не тиснуть один на один. Ця гіпотеза практично виконується для всієї досліджуваної балки, як на стінці так і на пояску, окрім областей примикання призматичних частин стержня до похилої частини, де має місце складна депланація пояску і концентрація 
напружень на стінці в місці переходу від меншої висоти стінки до більшої.

4. Гіпотеза про рівномірний розподіл дотичних напружень вздовж товщини стінки тонкостінного профілю. Ця гіпотеза не виконується для вільного пояску досліджуваної балки.

Як бачимо для зон вільного пояску перехідних областей стиків призматичних частин балки з похилою частиною, ніяка гіпотеза ні при яких значеннях геометричних параметрів не виконується. Ці перехідні області захоплюють як призматичні так і похилу частину. Перша і друга гіпотези не виконуються для вільного пояску похилої ділянки $\mathrm{i}$ прилягаючих до неї областей призматичних частин при доволі великих кутах нахилу $\alpha$. Проте при малих кутах нахилу $\alpha$ перша та друга гіпотези для пояска похилої ділянки на достатньому віддалені від місць стику 3 призматичними частинами задовільняются 3 точністю достатньою для технічних розрахунків. Четверта гіпотеза не $\epsilon$ критичною, вона введена лише для спрощення викладок розроблюваних теорій, аналогічно тому як в рамках класичної теорії згину балок врахування прогинів від зсуву проводиться у припущенні рівномірного розподілу дотичних напружень по висоті балки, хоча дійсний їх розподіл близький до отримуваних за формулою Журавського Д.І.

Що стосується універсальної балочної теорії, то ця теорія хоч і враховує деформацію поперечного перерізу у поперечному напрямі, на відміну від 1-шої гіпотези Власова-Уманського, проте вона насамперед розроблена саме для призматичних балок відкритого профілю, що апріорі унеможливлює iї застосування для похилої частини досліджуваної балки і прилягаючих призматичних частин, де має місце складна депланація пояску, особливо для великих значень кута нахилу $\alpha$.

Теорія Слівкера теж приймає деякі з гіпотез наведених вище (наприклад про незмінність контуру в поперечному напрямі, ненадавлювання поздовжніх шарів, рівномірність розподілу нормальних напружень по товщині), що вже унеможливлює їі використання для перехідних областей в місцях складної депланації і при великих кутах нахилу $\alpha$, хоча вона i враховує більш точний розподіл дотичних напружень в стінках стержня.

Рідше використовують повні оболонкові або пластинчасті моделі, наприклад в MCE-аналізі, у випадках коли кількість стержнів невелика, i/aбо вони мають доволі складний поперечний переріз, і при цьому потрібна підвищена точність компонентів НДС. Оболонкові (i в меншій мірі пластинчасті) моделі є більш точними у порівнянні 3 вищезгаданими. Проте навіть повні оболонкові/пластинчасті моделі враховують лінійний розподіл нормальних напружень по товщині і спрощені розподіли дотичних напружень по елементарному виділеному об'єму.

Дуже рідко використовують повну систему рівнянь об'ємної задачі теорії пружності, яка дає найбільш точні результати розподілу 
компонентів НДС по області конструкції. Оболонкові/пластинчасті i об'ємні моделі прямої задачі теорії пружності також використовують для пере-вірки, обгрунтування, визначення точності та встановлення області застосування тих чи інших наближених теорій, запропонованих для розрахунку тонкостінних конструкцій. Хоча точність НДС для оболонкових/пластичних моделей $є$ меншою у порівнянні з об'ємною моделлю, проте оболонкові моделі дозволяють реалізувати розрахунок стійкості, що не можна сказати про об'ємні моделі.

Підтвердженням вищесказаного можуть служити публікації [33] i [34]. Так в [33] проаналізовано НДС двотаврової балки зі змінною шириною пояску на дію згину з крученням застосовуючи оболонкову скінченно-елементну модель 3 врахуванням геометричної i фізичної нелінійностей, при роботі в пружній та пружно-пластичній областях. В публікації [34] запропонована модель розрахунку непризматичної тонкостінної конусоподібної балки відкритого профілю, довільного поперечного перерізу, де результати були перевірені $з$ використанням оболонкових скінченних елементів.

Для непризматичних балок навіть звичайна технічна теорія згину балок (ТТЗБ) формально не може бути застосована [35, с.76] по причині невиконання рівнянь рівноваги. ТТЗБ дає прийнятні результати для непризматичних балок, якщо зміна поперечного перерізу по довжині відбувається плавно і 3 невеликим градієнтом. В цьому випадку залежності ТТЗБ слід вважати наближеними. Вищезгадані теорії розрахунку тонкостінних стержнів теж були виведені в припущенні незмінності поперечного перерізу стержня/балки і тому дають прийнятні результати лише для призматичних стержнів. Для непризматичних тонкостінних стержнів розроблені теорії ї розрахунку слід застосовувати, якщо зміна поперечного перерізу по довжині відбувається плавно і з невеликим градієнтом.

Для випадку балки зі зламом стінки і пояску, представленої на рис. 1 при великих кутах $\alpha$ та малих радіусах скруглення $r$ умова плавної зміни поперечного перерізу не виконується, що $є$ причиною отримання апріорі недостовірних результатів, у випадку використання наближених теорій розрахунку тонкостінних стержнів.

Повертаючись до балки на рис. 1 можна провести наступну аналогію, згідно 3 якої, вирішення даної задачі можна порівняти 3 розрахунком багатоступінчатого стержня на міцність методами опору матеріалів. Застосовуючи гіпотези опору матеріалів для такого стержня, НДС в його прольотах можна визначити доволі точно, а в місцях стиків стержнів, де має місце концентрація напружень, ці гіпотези ніколи цих концентрацій не виявлять. Так само i в нашому випадку наближені гіпотези тонкостінних стержнів дадуть задовільні результати в призматичних частинах і на похилій ділянці (при малих кутах нахилу $\alpha$ ) на деякому віддалені від місць стиків/зламів. Проте в місцях стиків 
призматичних частин 3 похилою частиною, де має місце складна депланація вільного пояску, «тонкостінні» гіпотези (типу Власова В.3. та ін.) можуть давати апріорі незадовільні результати по ряду причин, викладених вище.

Аналіз п. 3. Розрахунок загальної, місцевої та викривленої стійкості тонкостінних стержнів. Власов В.З., грунтуючись на створеній ним теорії тонкостінних стержнів відкритого профілю, показав, що при деяких умовах стержень може втратити стійкість не в згинальній формі, а в згинально-крутильній, для якої значення критичної сили виявляється меншим, ніж для звичайної теорії поздовжнього згину. Самі ці обставини непередбачуваної поведінки тонкостінних стержнів змушують проводити інтенсивні дослідження їхнього НДС в цілому та їх частин зокрема, розраховуючи міцність і стійкість як правило одночасно.

Стійкість тонкостінного стержня розділяється на загальну та місцеву та викривлену. При втраті загальної стійкості може додатково відбуватися i втрата місцевої стійкості. Види загальної стійкості: поздовжня, поздовжньо-крутильна, крутильна, поперечно-крутильна. Поздовжня та поздовжньо-крутильна стійкість відносяться до Ейлерового типу стійкості і мають місце при дії стискуючих зовнішніх навантажень.

В публікації [36] проаналізовані методи та виявлені тенденції, які застосовуються при розрахунках місцевої стійкості.

Так в стандарті Єврокод 3 місцева втрата стійкості враховується методом «зменшеної ширини» тобто методом ефективної ширини, згаданим вище. Суть цього методу полягає в тому, що для поперечного пере-різу стисненого стержня ефект місцевої втрати стійкості пластинчастих елементів враховується шляхом заміни неоднорідного розподілу напружень на однорідний розподіл, що діє на зменшену частину пластинчатого елементу, при тій самій товщині. Вищевказаний метод нагадує метод зменшення площі в'язі, що втратила стійкість, запропонований Шиманським Ю.А., який застосовується при розрахунку еквівалентних брусів в декількох наближеннях.

Універсальна балочна теорія також придатна для розрахунку місцевої міцності, і публікації [28], [39] є яскравим тому підтвердженням. У дисертації [37] досліджується втрата стійкості фланцями для нетипових випадків враховуючи в тому числі пружно-пластичне деформування. У статті [38] також досліджуєтся втрата стійкості пластинчастими елементами при пружно-пластичному деформуванні методом Релея-Рітца. Для розрахунку місцевої втрати стійкості все частіше застосовується МCE у порівнянні з іншими методами, що пояснюється універсальністю та більшою точністю МСЕ і вузькою специфічністю решти методів, хоча останні дають меншу трудомісткість. У роботі [40] запропоновано оригінальний експериментально-теоретичний метод розрахунку несучої здатності непризматичних тонкостінних двотаврових стержнів змінного перерізу, що сходить на конус, з врахуванням місцевої стійкості стінки. 


\section{Аналіз п. 4. Визначення ефективної/приведеної ширини} пояску, викликаною зсувною затримкою та втратою стійкості пояску. Згадані вище теорії розрахунку тонкостінних стержнів для звичайних масових інженерних розрахунків $\epsilon$ відносно складними $\mathrm{i}$ трудо-місткими, коли на стадії проектування потрібно «прикинути» десятки варіантів, де не потрібна висока точність, а потрібна лише оцінка і якісне порівняння напружених станів різних опрацьовуваних варіантів між собою. Ці «тонкостінні» теорії реалізовуються як правило в чисельних моделях, в основному в МСЕ [20;31]. У таких випадках для широкополих балок застосовується поняття ефективної (приведеної, еквівалентної) ширини пояску балки. Як відомо з класичних курсів теорії пружності та розширених курсів опору матеріалів напруження в тонкостінних широкополих балках розподілені нерівномірно i відрізняються від тих, що визначаються згідно гіпотез опору матеріалів. $€$ дві основні причини цього явища: зсувна затримка і місцева втрата стійкості стиснених зон пояску. Для проведення інженерних розрахунків в рамках формул опору матеріалів застосовується/використовується так звана приведена (ефективна) ширина пояску балки, де напруження умовно приймаються рівномірно розподіленими вздовж ії ширини. В загальному випадку ефективна ширина - це змінна величина вздовж довжини балки або пластини. Зсувна затримка була відкрита Т. Карманом i розвинута С.П. Тимошенко і Дж. Гудьером в їх класичній праці «Теорія пружності» [41]. Слід відмітити, що ефективна ширина елементу 3 врахуванням місцевої втрати стійкості не пов'язана 3 ефективною шириною з врахуванням зсувного запізнення і визначається окремо [42].

Проблемі визначення приведеної ширини з врахуванням зсувної затримки присвячено дуже багато робіт як для простих так і складних випадків, де пластинчасті системи (напр. настили підкріплені ребрами жорсткості) розподіляються на окремі пластини 3 прикладенням невідомих зусиль по лініям їх контакту і знаходженням останніх з умов сумісності деформацій [53]. Як сказано в [47; 56] зсувна затримка вивчається впродовж декількох десятиліть, проте методи, застосовані у багатьох роботах, мають деякі неточності. Це пов'язано з відносною складністю явища і трудомісткістю його точної реалізації в загальному випадку, коли на балку діє довільне розподілене зовнішнє навантаження i зосереджені зусилля, вже не кажучи про їх довільне поєднання i непризматичність балок. Враховуючи відносну складність явища зсувної затримки, запропоновані наближені методики визначення приведеної ширини, напр. у [50]. Інтенсивно розвиваються чисельні методи (в основному МСЕ і його різновиди) розрахунку стержневих і балочних систем [43], [47]-[48] та ін., які враховують явище зсувної затримки, залежної від параметрів матриці жорсткості. В [44] вводять нові узагальнені функції переміщень для врахування ефекту зсувної затримки, 
яка в свою чергу досліджується енергетичним методом. Публікація [44] $\mathrm{\epsilon}$ цікавою за тією причиною, що тут доволі глибоко аналізується природа зсувної затримки. Зокрема у цій роботі відмічено, що в існуючих аналітичних методах деформація зсувної затримки приймається до уваги разом зі згинальною деформацією, що ускладнює процедуру врахування зсувної затримки. У цій же публікації запропоновано методику відокремлення деформації зсувної затримки від деформації згину, і досліджено зсувну затримку як окреме незалежне явище. Запропоновані наближені формули для врахування зсувної затримки і обчислення ефективної ширини.

У [46] отримано точне аналітичне рішення для ефективної ширини 3 врахуванням зсувної затримки для характерного коробчастого перерізу. У [49] знову працюють рядами Фур'є, а у [54] застосовують видозмінене рішення Файлона для дослідження ефективної ширини, застосовуючи метод полос.

У [45] порівнюють вплив зсувної затримки для різних трубчастих профілів. У [51]-[52] йде мова про негативну зсувну затримку, коли нормальні напруження біля стінки менші ніж на віддаленні від неї. Розрахунки окремих варіантів досліджуваного вузла на рис. 1 об'ємними СЕ показали наявність негативної зсувної затримки у вільному пояску нахиленої ділянки для деяких варіантів геометрії. Зсувній затримці присвячено і багато інших робіт, які перекликаються з вищенаведеними по характеру і напрямам дослідження, і які можна систематизувати за основними напрямами: чисельні методи, аналітичні методи, спрощені методи врахування зсувної затримки і розрахунку ефективної ширини; при пружному та пружно-пластичному деформуванні; для ізотропних (металів в основному) та композитних матеріалів (в основному залізобетону), тощо. При створенні спрощених/наближених методик i формул для визначення приведеної ширини 3 врахуванням зсувної затримки слід визначити компроміс між простотою і точністю обчислень та областю застосування. Тому що як показано в роботі [55], де порівнюється обчислення приведеної ширини (редукційного коефіцієнту) за Британським та Японським стандартами для одних i тих же конструкцій, хоча результати розрахунків значень приведеної ширини в цілому узгоджуються між собою для типових випадків, проте різниця в деяких випадках може сягати до 50 \%. Вищенаведене дає зайві доводи для використання повної об'ємної моделі теорії пружності для проведення серійних досліджень НДС вузла.

Публікація [56] присвячена проблемі визначення ефективної ширини при роботі пояску у пружній та пружно-пластичній областях, що для останнього (пружно-пластичного) питання є рідкістю навіть для сьогоднішнього часу. В цій статті представлено порівняння різних стандартів стосовно визначення ефективної ширини, а також відмічено, 
що неправильне обчислення ефективної ширини мостових конструкцій стало причиною їх катастроф, перелічених в цій роботі.

Можна зробити висновок, що проблема визначення ефективної ширини при пружному та пружно-пластичному деформуванні $\epsilon$ актуальною навіть на сьогоднішній день.

Проблема визначення ефективної ширини пояску з врахуванням місцевої втрати його стійкості має місце для стиснених поясків і вже пояснювалася в рамках методу ефективної ширини та/або «зменшеної» ширини Єврокоду 3. Ця проблема часто вивчається з врахуванням різного роду нелінійностей. Ця тема розвивається як для ізотропних так $\mathrm{i}$ композитних матеріалів (в основному для залізобетону) і вивчається незалежно від проблеми міцності.

Аналіз п. 5. Розрахунки при динамічних навантаженнях, ударі та вібрації. Огляд літератури показав, що дослідження в області динамічних розрахунків, удару, вільних коливань і вимушеної вібрації тонкостінних стержнів відбувається в основному з використанням теорії Власова і Уманського та їх модифікацій, рідше Слівкера та інших авторів. Застосовуються і оболонкові моделі, як для самостійних досліджень так і для перевірки наближених моделей, створених на базі вищезгаданих теорій. Динамічні моделі реалізуються в основному в рамках МСЕ та його різновидів, по причині того, що динамічні моделі в МСЕ відносно легко реалізуються поверх статичної моделі. Розрахунки при динамічних навантаженнях, при ударі та вібрації реалізуються на базі матриці жорсткості і матриці мас.

В публікаціях [57], [58] представлено дослідження вібрації тонкостінних стержнів 3 використанням теорії Власова. В [57] були досліджені непризматичні стержні відкритого профілю з використанням поліномів Лежандра, які були застосовувалися для вирішення отриманих диференціальних рівнянь. В [58] декількома методами отримані рівняння для дослідження вібрації, проведені експериментальні випробування, що під-тверджують узгодженість результатів.

C i iнші шляхи дослідження динаміки. Так у праці [59] представлено дослідження вібрації із застосуванням так званого уніфікованого формулювання Каррери. Формулювання Каррери $\epsilon$ ієрархічним формулюванням, що враховує кількість ступенів свободи моделі $N$, як вільний параметр (тобто як вхідне дане). В межах цього формулювання моделі балок Ейлера-Бернуллі та Тимошенко є окремими випадками. Спостерігається зростаюча кількість публікацій, присвячених цьому методу, розробленого професором Е. Carrera.

В роботі [60] запропоновані моделі динамічних досліджень тонкостінних стержнів використовуючи теорію Слівкера. В [61] запропоновано модель динамічного аналізу тонкостінних конусоподібних балок закритого профілю, на прикладі вітряної лопаті, застосовуючи спектральний метод скінченних елементів, де перевірка отриманих 
результатів була проведена 3 використанням оболонкових скінченних елементів.

Досліджувана балка на рис. 1 часто встановлюється в машинному відділені судна і зазнає вібраційних навантажень та удару в процесі експлуатації.

Аналіз п. 6. Дослідження впливу зварного шва на загальний НДС конструкції. Як відомо зварювальні шви $є$ причиною виникнення в конструкції додаткових напружень. Ці напруження називаються залишковими і представляють собою додаткову пружну складову до діючих напружень, викликаних дією зовнішніх факторів. Для тонкостінних конструкцій залишкові напруження, викликаних наявністю зварних швів, призводять до викривлення пластинчастих елементів $\mathrm{i}$ тонкостінної поверхні, що потрібно враховувати при розрахунках, особливо стійкості. В районі наявності зварних швів виникають в основному розтягувальні залишкові напруження, що пояснюється тим, що після зварювання, коли метал зварного шва, вже нанесений $\mathrm{i}$ приплавлений на основний зварювальний метал, під час охолодження зменшується у розмірах і тягне за собою основний метал на який він був нанесений.

Серед спрощених методик для визначення напружень від зварних швів можна виділити методику представлену в [62].

Аналіз п. 7. Дослідження втомної міцності зварних швів. Тема втомної міцності зварних швів $\epsilon$ дуже широкою темою $\mathrm{i}$ доволі самостійною, не прив'язаною в загальному випадку до тонкостінних конструкцій і яка не може біти навіть коротко охоплена в рамках даної роботи. Тема втомної міцності з самого початку свого розвитку базується на експериментальних дослідженнях і тому має різні напрями, моделі, методики, способи розрахунку як при пружному так i пружнопластичному деформуванні. Стосовно досліджуваної балки на рис. 1 тема втомної міцності зварного шву є дуже актуальною, тому що зварний шов, що з'єднує вільний поясок і стінку в місці переходу від меншої висоти стінки до похилої ділянки часто руйнується по причині того, що в цій області має місце відразу декілька концентраторів напружень, викликаних особливостями геометрії вузла, вже не кажучи про концентрацію напружень у самому зварному шві; в цьому місці переходу спостерігається максимум деформацій викликаних депланацією.

Аналіз п. 8. Оптимальне проектування тонкостінних стержнів. Оптимальне проектування тонкостінних конструкцій є також широкою темою, яка має різні способи реалізації. Основна мета дослідження при оптимальному проектування тонкостінних конструкцій $є$ пошук цільової функції, що підлягає мінімізації (або максимізації) та оптимальних параметрів. Мінімізація по площі поперечного перерізу 3 метою забезпечення мінімальної маси конструкції є доволі наївною, хоча і іноді застосовуваною. При складанні цільової функції для балки, зображеної на 
рис. 1 бажано враховувати наявність зварного шву як необхідного технологічного фактору.

Існує маса публікацій присвячених оптимальному проектуванню тонкостінних конструкцій. В [63] запропоновано визначення оптимальних залежностей геометричних розмірів балки з врахуванням забезпечення місцевої стійкості стінки і полиці. В публікації [64] представлена методика оптимального проектування двотаврової конусоподібної балки в умовах поперечно-крутильної втрати стійкості, фактору що найбільш розповсюджений для тонкостінних балок. В [65] запропоновано методику оптимального проектування двотаврових зварних балок 3 врахування зварювальних робіт.

Досліджуваний вузол, що представляє собою вищеобговорювану балку зі зламом стінки i пояску збирається 3 металевих листів, поверхневий шар яких в загальному випадку $\epsilon$ анізотропним, що $\epsilon$ наслідком прокату, та інших технологічних процесів, виконуваних над листами, таких як механічне деформування в процесі виготовлення вузла, механічні, термічні i можливо хімічні обробки. Анізотропність змінюється по товщині, а поблизу зварного шва механічні характеристики металу є іншими ніж на віддалені від нього. Все це призводить до того, що різні зони вузла будуть мати різні механічні характеристики у різних напрямах. Тому в дійсності для дослідження вузла приймається модель пружно-пластичного тіла 3 анізотропним зміцненням. Складність полягає не в реалізації такої моделі, а у визначенні механічних характеристик листів для різних зон конструкції в цілому. Як правило балки, зображені на рис. 1, в основному $\epsilon$ сталевими як більшість суднобудівних конструкцій, рідше 3 алюмінієвих сплавів. Аналіз праць присвячених дослідженню НДС у пружно-пластичній області, згаданих вище і не тільки, показав, що в основному використовується модель ідеального пружно-пластичного тіла без зміцнення (з горизонтальною площадкою текучості), без врахування ефекту Баушингера.

\section{Висновки}

1. Теорії розрахунку тонкостінних стержнів Власова, Уманського, Слівкера, Універсальна балочна теорія, метод скінченних смуг, метод Каррери та ін. не придатні для розрахунку балки зі зламом стінки та пояску, представленої на рис. 1, по причині того, що: a) ці теорії були розроблені для призматичних стержнів, і можуть в крайньому випадку застосовуватися для конусоподібних балок з невеликим градієнтом зміни поперечного перерізу, що не виконується для досліджуваної балки на рис. 1 в областях стику призматичних частин 3 похилою частиною, та при великих кутах нахилу стінки $\alpha$, і малих радіусах скруглення $r$; б) в місцях стику призматичних частин досліджуваної балки 3 похилою частиною (тобто в місцях зламу пояску) має місце повний тензор напружень, 
складна депланація пояску, концентратори напружень, що унеможливлює ні при яких умовах застосування ніяких наближених теорій розрахунку тонкостінних стержнів для досліджуваної балки на рис. 1.

Для дослідження НДС балки на рис. 1 однозначно потрібно використовувати оболонкові або об’ємні моделі теорії пружності.

2. Обчислення ефективної ширини 3 врахуванням зсувної затримки для вільного пояску похилої частини повинно бути реалізовано 3 врахуванням того, що в пояску має місце повний тензор напружень. Пот-рібно проаналізувати можливість застосування як класичної методики, так розглянути/розробити i альтернативні методики, які б підтверджувалися відповідними перевірками. Ефективна ширина повинна розраховуватися як при пружному так i пружно-пластичному деформуванні, по всій довжині похилої частини, по можливості захоплюючи прилягаючі області призматичних частин.

3. Дослідження НДС досліджуваної балки зі зламом стінки i пояску, в тому числі методика розрахунку ефективної ширини вільного пояску, а також оптимальне проектування досліджуваної балки в цілому повинні бути реалізовані як з врахуванням втрати місцевої стійкості, так і без їі врахування.

\section{СПИСОК ЛІЕРАТУРИ}

1. Det Norske Veritas and Germanischer Lloyd. Rules for classification: Ships. Part 3. Hull. Oslo: DNV GL AS, 2019. 776 p.

2. Lloyd's Register. Rules and Regulations for the Classification of Ships. London : Lloyd's Register Group Limited, 2019. 1754 p.

3. Russian maritime register of shipping. Rules for the classification and construction of sea-going ships. Part II. Hull. ND No. 2-020101124-E. Russia, Saint-Petersburg, 2020. 276 p.

4. American Bureau of Shipping. Rules for building and classing marine vessels. Part 3. Hull construction and equipment. 1701 City Plaza Drive Spring, TX 77389 USA, 2020. 553 p.

5. Российский речной Регистр. Правила классификаџии и постройки судов (ПКПС) / Отв. за выпуск Н.А. Ефремов Москва, 2019. $1506 \mathrm{c}$.

6. ДБН В.2.6-198:2014. Державні будівельні норми України. Сталеві конструкиії. Норми проектування. [На заміну ДБН B.2.6-163:2010 у ч. розд. 1 та ДСТУ Б В.2.6-194:2013; Чинний від 2015-01-01]. Вид. офіи. Київ : Мінрегіон Украӥни, 2014. 199 с.

7. ТКП ЕN 1993-1-1-2009 (02250). Еврокод 3. Проектирование стальных конструкций. Часть 1-1. Общчие правила и правила для зданий (EN 1993-1-1:2005, IDT). [Действителен от 10 дек. 2009 г.] Минск: Минстройархитектуры, 2009. 85 с. 
ВІСНИК

ОДЕСЬКОГО НАЦІОНАЛЬНОГО

МОРСЬКОГО УНІВЕРСИТЕТУ № 3 (63), 2020
HERALD

OF THE ODESSA NATIONAL

MARITIME UNIVERSITY

8. ТКП ЕN 1993-1-5-2009*(02250). Еврокод 3. Проектирование стальных конструкций. Часть 1-5. Пластинчатые элементы конструкиий (EN 1993-1-5:2006, EN 1993-1-5:2006/AC:2009, IDT). Минск: Минстройархитектуры, 2014. 51 c.

9. СП 294. 1325800.2017. Конструкиии стальные. Правила проектирования. [Действителен от 01 дек. 2017 г.]. Москва: Минстрой России, 2017. 158 c.

10. ANSI/AISC 360-16. American Institute of Steel Construction (AISC). Specification for structural steel buildings. [Supersedes the Specification for Structural Steel Buildings dated June 22, 2010 and all previous versions of this specification; Actual from July 7, 2016]. USA, Chicago, IL : AISC, 2016. 620 p.

11. Arya C. Design of structural elements: concrete, steelwork, masonry and timber designs to British standards and Eurocodes: 3-rd ed. CRC Press, 2009. 495 p.

12. Богданович А.У. Тонкостенные стержни переменного сечения: монография. Казань: Казанский гос. архитектурно-строительный ун-т., 2008. $323 \mathrm{c}$.

13. Суслов В.П., Баландин А.А. О редукиионном коэффициенте пояска балки, имеющей излом оси. Тез. докл. Всесоюз. науч.-техн. конф. по проблемам прочности и конструирования крупнотоннажных судов. Л.: Судостроение, 1972. Вып. 182. С. 123-129.

14. Суслов В.П., Баландин А.А. Редукиионный коэффициент пояска в районе его излома. Труды конференции по повреждениям и эксплуатационной надежсности судовых конструкиий. Владивосток: ДВПИ, 1972. 0,4 п.л.

15. Суслов В.П., Баландин А.А. Приближенное теоретическое решение задачи о напряженном состоянии балок, имеющих изломы поясков. Судостроение и морские сооружения. Харьков: ХГУ, 1973. Bbin. 20. 0,5 п.л.

16. Ascione L., Berardi V., Feo L., Fraternali F., Tralli A. M. Nonprismatic thin-walled beams: critical issues and effective modeling. Proceedings of AIMETA 2017 XXIII Conference, Salerno, Italy, 4-7 September 2017. Salerno, 2017. pp. 301-308.

17. Коростильов Л.І., Соков В.М. Оиенка концентрации напряжений в типовых очагах конструктивных узлов корпуса судна. Збірник наукових праџь НУК. Миколаїв: НУК, 2008. № 5 (422). C. 11-17.

18. Соков В.М., Коростильов Л.І. Кониентрация напряљений в типовом очаге тонкостенных конструкиий. Збірник наукових працьь НУК. Миколаїв: НУК, 2010. № 1 (430), С. 10-16.

19. Соков В.М., Коростильов Л.І. Проектирование конструктивного узла корпуса судна с учетом технологических факторов. 
ВІСНИК

ОДЕСЬКОГО НАЦІОНАЛЬНОГО

МОРСЬКОГО УНІВЕРСИТЕТУ

№ 3 (63), 2020
HERALD

OF THE ODESSA NATIONAL

MARITIME UNIVERSITY

№ 3 (63), 2020

Збірник наукових праџьь НУК. Миколаїв: НУК, 2010. № 5 (434), C. 3-10.

20. Рыбаков В.А., Гамаюнова, О.С. Напряженно-деформированное состояние элементов каркасных сооружений из тонкостенных стержней. Интернет-журнал "Строительство уникальных зданий и сооружений». СПб.: Санкт-Петербургский политехнический университет Петра Великого, 2013. № 7 (12). C. 79-123.

21. Власов В.3. Тонкостенные упругие стержни. Москва: Гос. изд-во физико-математической лит-ры, $1959.574 \mathrm{c}$.

22. American Iron and Steel Institute. Direct strength method design guide. Washington, DC, USA, 2006. $171 \mathrm{p}$.

23. Cheung, Y.K. Finite strip method in structural analysis. Oxford: Pergamon, 1976. 244 p.

24. Schardt, $R$. Verallgemeinerte Technische Biegetheorie: lineare Probleme. Springer-Verlag, 1989. 362 p. (in German).

25. Уманский А.А. Изгиб и кручение тонкостенных авиачионных конструкиий. М.: Оборониздат, 1939. 112 c.

26. Schafer, B.W. Designing cold-formed steel using the direct strength method. Proceedings of 18th International Specialty Conference on Cold-Formed Steel Structures October 26-27, 2006, Orlando, Florida. Orlando, Florida, 2006. pp. 475-489.

27. Li Z., Schafer, B. W. Application of the finite strip method in coldformed steel member design. Journal of Constructional Steel Research. Elsevier, 2010. Vol. 66, iss. 8-9, pp. 971-980.

28. Henriques, D., Gonçalves, R., Camotim, D. A physically non-linear GBT-based finite element for steel and steel-concrete beams including shear lag effects. Thin-Walled Structures. Elsevier, 2015. vol. 90, pp. 202-215.

29. Сливкер В.И. Строительная механика. Вариационные основы. Учебное пособие. М.: АСВ, 2005. 736 c.

30. Рыбаков В.А. Применение полусдвиговой теории В.И. Сливкера для анализа напряженно-деформированого состояния систем тонкостенных стержней: автореф. дис. ... канд. техн. наук: 01.02.04. Санкт-Петербург, 2012. 21 c.

31. Советников Д.О., Азаров А.А., Иванов С.С., Рыбаков В.А. Методы расчета тонкостенных стержней: статика, динамика, yстойчивость. Alfabuild. СПб: Санкт-Петербургский политехнический университет Петра Великого, 2018. № 2(4), С. 7-33.

32. Дьяков С.Ф. Сравнительный анализ задачи кручения тонкостенного стержня по моделям Власова и Сливкера. Строи- 
ВІСНИК

ОДЕСЬКОГО НАЦІОНАЛЬНОГО

МОРСЬКОГО УНІВЕРСИТЕТУ № 3 (63), 2020
HERALD

OF THE ODESSA NATIONAL

MARITIME UNIVERSITY

тельная механика инженерных конструкичй и сооружений. М.: Российский университет дружбы народов, 2013. №1, С. 24-31.

33. El-Mahdy, G.M., El-Saadawy, M.M. Ultimate strength of singly symmetrical I-section steel beams with variable flange ratio. ThinWalled Structures. Elsevier, 2015. vol. 87, pp. 149-157.

34. Asgarian, B., Soltani, M., Mohri F. Lateral-torsional buckling of tapered thin-walled beams with arbitrary cross-sections. Thin-walled structures. Elsevier, 2013. vol. 62, pp. 96-108.

35. Суслов В.П., Кочанов Ю.П., Спихтаренко В.Н. Строительная механика корабля и основы теории упругости. Л.: Судостроение, $1972.720 \mathrm{c}$.

36. Трубина Д.А., Кононова Л.А., Кауров А.А., Пичугин Е.Д., Абдулаев Д.А. Местная потеря устойчивости стальных холодногнутых профилей в условиях поперечного изгиба. Строительство уникальных зданий и сооружений. СПб.: Санкт-Петербургский политехнический университет Петра Великого, 2014. № 4(19), C. 109-127.

37. Bassam, Adib Burgan. Special problems in wide and narrow stiffened compression flanges: PhD thesis / University of London. London, 1987. 356 p.

38. Hughes, O.F., Ma, M. Inelastic analysis of panel collapse by stiffener buckling. Computers \& structures. Elsevier, 1996. Vol. 61, No. 1. pp. 107-117.

39. Schardt, R. Generalized beam theory - an adequate method for coupled stability problems. Thin-walled structures. Elsevier, 1994. Vol. 19, iss. 2-4. pp. 161-180.

40. Скляров I.O. Експериментально-теоретична методика розрахунку сталевих рам зі зварних двотаврів змінного перерізу 3 гнучкою стінкою. Містобудування та територіальне планування. Київ: Київський національний університет будівництва $i$ архітектури, 2014. № 52, C. 381-386.

41. Timoshenko, S.P., Goodier, J.N. Theory of Elasticity: 3rd ed. New York: McGraw-Hill Book Company, 1970. 567 pp.

42. Надольский В.В., Дергачев М.Г. Учет сдвигового запаздьввания согласно требованиям ТКП ЕN 1993-1-5. Инновационная подготовка инженерных кадров на основе европейских стандартов (Еврокодов): материаль международной научн.-техн. конф., Минск, 30 мая 2017 г. Минск: БНТУ, 2017. С. 109-117.

43. Kraus, M. Numerical approach for bending stress ascertainment in beam theory considering effects of elastic shear lag. Engineering Structures and Technologies. / Vilnius Gediminas Technical University. Vilnius : Taylor \& Francis Group, 2017. Vol. 9, iss. 1. pp. 1-8. 
44. Zhang, Y.H., Lin, L.X. Shear lag analysis of thin-walled box girders based on a new generalized displacement. Engineering Structures. Elsevier, 2014. Vol. 61, pp. 73-83.

45. Mazinani, I., Jumaat, M.Z., Ismail, Z., Chao, O.Z. Comparison of shear lag in structural steel building with framed tube and braced tube. Structural Engineering and Mechanics. Korea, 2014. Vol. 49, № 3. pp. 297-309.

46. Zhou, W.B., Jiang, L.Z., Liu, Z.J., Liu, X.J. Closed-form solution to thin-walled box girders considering effects of shear deformation and shear lag. Journal of Central South University. Germany: Springer, 2012. № 19. pp. 2650-2655.

47. Zhang, Y.H. Improved finite-segment method for analyzing shear lag effect in thin-walled box girders. Journal of Structural Engineering. USA: ASCE, 2011. Vol. 138, iss. 10. pp. 1279-1284.

48. Zhou, S.J. Finite beam element considering shear-lag effect in box girder. Journal of Engineering Mechanics. USA: ASCE, 2010. Vol. 136, iss. 9. pp. 1115-1122.

49. Tahan, N., Pavlovic, M., N., Kotsovos, M.D. Shear-lag revisited: The use of single Fourier series for determining the effective breadth in plated structures. Computers \& structures. Elsevier, 1997. Vol. 63, iss. 4. pp. 759-767.

50. Sedlacek G., Bild S. A simplified method for the determination of the effective width due to shear lag effects. Journal of Constructional Steel Research. Elsevier, 1993. Vol. 24, iss. 3. pp. 155-182.

51. Kristek, V., Studnicka, J. Negative shear lag in flanges of plated structures. Journal of structural engineering. USA: ASCE, 1991. Vol. 117, iss. 12. pp. 3553-3569.

52. Shushkewich, K.W. Negative shear lag explained. Journal of structural engineering. USA: ASCE, 1991. Vol. 117, iss. 11. pp. 3543-3546.

53. Папкович П.Ф. Теория упругости. Москва, Ленинград, Киев: Оборонгиз, 1939. 640 c.

54. Кириленко В.Ф. Применение видоизмененного решения Файлона в пространственных расчетах коробчатых балок. Збірник наукових пращь Украйнського інституту сталевих конструкцій імені В.М. Шимановського. Київ: Сталь, 2009. № 3. С. 210-220.

55. Wang, H., Wang, Q., Qin, S. Effective Flange Width of Steel Box Girder Bridge According to British Specifications and Japanese Specifications: Proceedings of the 2017 3-rd International Forum on Energy, Environment Science and Materials (IFEESM 2017), Shenzhen, China, November 25-26, 2017. Atlantis Press, 2017. Vol. 120. pp. 1364-1368. 
56. Yemelin, Y. On the effective width of girder flanges in elastic and elasto-plastic stages. Journal of Constructional Steel Research. Elsevier, 1992. Vol. 21, iss. 1-3. pp. 195-204.

57. Szybinski, J., Ruta, P. Analysis of thin-walled beams with variable monosymmetric cross section by means of Legendre polynomials. Studia Geotechnica et Mechanica. Sciendo, 2019. Vol. 41, iss. 1. pp. 1-12.

58. Ambrosini, D. On free vibration of nonsymmetrical thin-walled beams. Thin-Walled Structures. Elsevier, 2009. Vol. 47, iss. 6-7. pp. 629-636.

59. Pagani, A., Carrera, E., Ferreira, A.J.M. Higher-order theories and radial basis functions applied to free vibration analysis of thinwalled beams. Mechanics of Advanced Materials and Structures. Taylor \& Francis Group, 2016. Vol. 23, iss. 9. pp. 1080-1091.

60. Rybakov, V., Dyakov, S., Sovetnikov, D., Azarov, A., Ivanov, S. Finite elements apparatus in thin-walled rods dynamics problems. MATEC Web of Conferences : Proceedings of International Scientific Conference on Energy, Environmental and Construction Engineering (EECE-2018). EDP Sciences, 2018. Vol. 245, Article Number 08007. pp. $1-8$.

61. Shen, Y., Zhu, Z., Wang, S., Wang, G. Dynamic analysis of tapered thin-walled beams using spectral finite element method. Shock and Vibration. Hindawi, 2019. Vol. 2019, Article ID 2174209, pp. 1-13.

62. Михайленко Т.Г. О напряжённом состоянии сварных узлов стальных конструкиий. Технические науки - от теории к практике. Новосибирск: “Сибирская академическая книга», 2013. № 22. C. 50-55.

63. Слипич А.А., Мовчан И.А. Оптимальное проектирование стальных балок двутаврового сечения. Вісник Криворізького начіонального університету. Кривий Ріг: КНУ, 2012. Вип. 33. C. $38-40$.

64. Ozbasaran H., Yilmaz T. Shape optimization of tapered I-beams with lateral-torsional buckling, deflection and stress constraints. Journal of Constructional Steel Research. Elsevier, 2018. № 143. pp. 119-130.

65. Mela, K., Heinisuo, M. Weight and cost optimization of welded high strength steel beams. Engineering structures. Elsevier, 2014. № 79. pp. 354-364.

\section{REFERECES}

1. Det Norske Veritas and Germanischer Lloyd. (2019). Rules for classification: Ships. Part 3. Hull. Oslo: DNV GL AS. 
2. Lloyd's Register. (2019). Rules and Regulations for the Classification of Ships. London: Lloyd's Register Group Limited.

3. Russian maritime register of shipping. (2020). Rules for the classification and construction of sea-going ships. Part II. Hull. ND No. 2-020101-124-E. Saint-Petersburg: RMRS.

4. American Bureau of Shipping. (2020). Rules for building and classing marine vessels. Part 3. Hull construction and equipment. 1701 City Plaza Drive Spring, TX 77389 USA: ABS.

5. Yefremov, N.A. (2019). Rossiyskiy rechnoy Registr. Pravila klassifikatsii $i$ postroyki sudov (PKPS). [Russian river register. Rules of classification and building of ships]. Moscow: RRR. (in Russian).

6. DBN V.2.6-198:2014. (2014). Derzhavni budivelni normy Ukrainy. Stalevi konstruktsii. Normy proektuvannia. [Ukrainian national structural rules. Steel constructions. Design rules]. Kyiv: Minrehion Ukrainy. (in Ukrainian).

7. TKP YeN 1993-1-1-2009 (02250). (2009). Yevrokod 3. Proyektirovaniye stalnykh konstruktsiy. Chast 1-1. Obshchiye pravila $i$ pravila dlya zdaniy (EN 1993-1-1:2005, IDT). [Eurocode 3. Design of steel constructions. Part 1-1. General rules and rules for buildings]. Minsk: Minstroyarkhitektury. (in Russian).

8. TKP EN 1993-1-5-2009* (02250). (2014). Yevrokod 3. Proyektirovaniye stalnykh konstruktsiy. Chast 1-5. Plastinchatyye elementy konstruktsiy (EN 1993-1-5:2006, EN 1993-1-5:2006/AS:2009, IDT). [Eurocode 3. Design of steel constructions. Part 1-5. Plate elements of constructions]. Minsk: Minstroyarkhitektury. (in Russian).

9. SP 294. 1325800.2017. (2017). Konstruktsii stalnyye. Pravila proyektirovaniya. [Steel constructions. Design rules]. Moscow: Minstroy Rossii. (in Russian).

10. ANSI/AISC 360-16. (2016). American Institute of Steel Construction (AISC). Specification for structural steel buildings. USA, Chicago, IL: AISC.

11. Arya, C. (2009). Design of structural elements: concrete, steelwork, masonry and timber designs to British standards and Eurocodes (3-rd ed.). CRC Press.

12. Bogdanovich, A.U. (2008). Tonkostennyye sterzhni peremennogo secheniya: monografiya. [Thin-walled rods of variable crosssection: monography]. Kazan: Kazan State University of Architecture and Engineering. (in Russian).

13. Suslov, V.P., Balandin, A.A. (1972). O reduktsionnom koeffitsiyente poyaska balki, imeyushchey izlom osi. [About reduction factor of a girdle of a beam having a break of an axis]. Proceedings of Vsesoyuz. nauch.-tekhn. konf. po problemam 
prochnosti $i$ konstruirovaniya krupnotonnazhnykh sudov. Leningrad: Sudostro-yeniye, vol. 182, pp. 123-129. (in Russian).

14. Suslov V.P., Balandin A.A. (1972). Reduktsionnyy koeffitsiyent poyaska $v$ rayone yego izloma. [Reduction factor of a girdle in the regions of its break]. Proceedings of Konferentsii po povrezhdeniyam $i$ ekspluatatsionnoy nadezhnosti sudovykh konstruktsiy. Vladivostok: DVPI, 0.4 p.s. (in Russian).

15. Suslov V.P., Balandin A.A. (1973). Priblizhennoye teoreticheskoye resheniye zadachi o napryazhennom sostoyanii balok, imeyushchikh izlomy poyaskov. [Approximate theoretical solution of the problem of stress state of beams with breaks of girdles]. Sudostroyeniye $i$ morskiye sooruzheniya, vol. 20, 0.5 p.s. (in Russian).

16. Ascione L., Berardi V., Feo L., Fraternali F., Tralli A. M. (2017). Non-prismatic thin-walled beams: critical issues and effective modeling. Proceedings of AIMETA 2017 XXIII Conference, (Salerno, Italy, 4-7 September 2017). Salerno, pp. 301-308.

17. Korostilov L.I., Sokov V. M. (2008). Otsenka kontsentratsii napryazheniy $v$ tipovykh ochagakh konstruktivnykh uzlov korpusa sudna. [Estimation of the stress concentration in the typical hotbeds of structural assemblies of ship hull]. Zbirnyk naukovykh prats NUK, no. 5 (422), pp. 11-17. (in Russian).

18. Sokov, V.M., Korostilov, L.I. (2010). Kontsentratsiya napryazheniy $v$ tipovom ochage tonkostennykh konstruktsiy. [Stress concentration in the typical hotbed of thin-walled constructions]. Zbirnyk naukovykh prats NUK, no. 1 (430), pp. 10-16. (in Russian).

19. Sokov, V.M., Korostilov, L.I. (2010). Proyektirovaniye konstruktivnogo uzla korpusa sudna s uchetom tekhnologicheskikh faktorov. [Design of the structural assembly of ship hull considering technology factors]. Zbirnyk naukovykh prats NUK, no. 5 (434), $\quad$ pp. 3-10. (in Russian).

20. Rybakov, V.A., Gamayunova, O.S. (2013). Napryazhenno-deformirovannoye sostoyaniye elementov karkasnykh sooruzheniy iz tonkostennykh sterzhney. [Stress-strain state of elements of wireframe structures fabricated of thin-walled rods]. Internetzhurnal «Stroitelstvo unikalnykh zdaniy i sooruzheniy», no. 7 (12), pp. 79-123. (in Russian).

21. Vlasov, V.Z. (1959). Tonkostennyye uprugiye sterzhni. [Thinwalled elastic rods]. Moscow: Gos. izd-vo fiziko-matematicheskoy lit-ry. (in Russian).

22. American Iron and Steel Institute. (2006). Direct strength method design guide. Washington, DC, USA: AISI. 
23. Cheung, Y.K. (1976). Finite strip method in structural analysis. Oxford: Pergamon.

24. Schardt, R. (1989). Verallgemeinerte Technische Biegetheorie: Lineare Probleme. Berlin: Springer-Verlag. (in German).

25. Umanskiy, A.A. (1939). Izgib i krucheniye tonkostennykh aviatsionnykh konstruktsiy. [Bending and torsion of thin-walled aviation constructions]. Moscow: Oboronizdat. (in Russian).

26. Schafer, B. W. (2006). Designing cold-formed steel using the direct strength method. Proceedings of 18th International Specialty Conference on Cold-Formed Steel Structures (October 26-27, 2006, Orlando, Florida). Orlando, Florida. pp. 475-489.

27. Li, Z., Schafer, B.W. (2010). Application of the finite strip method in cold-formed steel member design. Journal of Constructional Steel Research, vol. 66, iss. 8-9, pp. 971-980.

28. Henriques, D., Gonçalves, R., Camotim, D. (2015). A physically non-linear GBT-based finite element for steel and steel-concrete beams including shear lag effects. Thin-Walled Structures, vol. 90, pp. 202-215.

29. Slivker, V.I. (2005). Stroitelnaya mekhanika. Variatsionnyye osnovy. Uchebnoye posobiye. [Structural mechanics. Variational basics. Textbook]. Moscow: ASV. (in Russian).

30. Rybakov, V.A. (2012). Primeneniye polusdvigovoy teorii V.I. Slivkera dlya analiza napryazhenno-deformirovanogo sostoyaniya sistem tonkostennykh sterzhney. [Application of the semishear theory of V.I. Slivker for analyzing of stress-strain state of thin-walled rod systems]. (PhD thesis), Saint-Petersburg: Peter the Great St-Petersburg Polytechnic University. (in Russian).

31. Sovetnikov, D.O., Azarov, A.A., Ivanov, S.S., Rybakov, V.A. (2018). Metody rascheta tonkostennykh sterzhney: statika, dinamika, ustoychivost. [Methods of calculation of thin-walled rods: statics, dynamics, stability]. Alfabuild, no. 2(4), pp. 7-33. (in Russian).

32. Dyakov, S.F. (2013). Sravnitelnyy analiz zadachi krucheniya tonkostennogo sterzhnya po modelyam Vlasova $i$ Slivkera. [Comparative analysis of the problem of torsion of thin-walled rod using models of Vlasov and Slivker]. Stroitelnaya mekhanika inzhe-nernykh konstruktsiy i sooruzheniy, no. 1, pp. 24-31. (in Russian).

33. El-Mahdy, G.M., El-Saadawy, M.M. (2015). Ultimate strength of singly symmetrical I-section steel beams with variable flange ratio. Thin-Walled Structures, vol. 87, pp. 149-157. 
34. Asgarian, B., Soltani, M., Mohri, F. (2013). Lateral-torsional buckling of tapered thin-walled beams with arbitrary crosssections. Thin-walled structures, vol. 62, pp. 96-108.

35. Suslov, V.P., Kochanov, Yu.P., Spikhtarenko, V.N. (1972). Stroitelnaya mekhanika korablya $i$ osnovy teorii uprugosti. [Structural mechanics of ship and basis of theory of elasticity]. Leningrad: Sudostroyeniye. (in Russian).

36. Trubina, D.A., Kononova, L.A., Kaurov, A.A., Pichugin, Ye.D., Abdulayev, D.A. (2014). Mestnaya poterya ustoychivosti stalnykh kholodnognutykh profiley $v$ usloviyakh poperechnogo izgiba. [Local buckling of steel cold-formed profiles in conditions of lateral bending]. Stroitelstvo unikalnykh zdaniy i sooruzheniy, no. 4(19), pp. 109-127. (in Russian).

37. Bassam, Adib Burgan. (1987). Special problems in wide and narrow stiffened compression flanges. (PhD thesis). London: University of London.

38. Hughes, O.F., Ma, M. (1996). Inelastic analysis of panel collapse by stiffener buckling. Computers \& structures, vol. 61, no. 1 , pp. 107-117.

39. Schardt, R. (1994). Generalized beam theory - an adequate method for coupled stability problems. Thin-walled structures, vol. 19, iss. 2-4, pp. 161-180.

40. Skliarov, I.O. (2014). Eksperymentalno-teoretychna metodyka rozrakhunku stalevykh ram zi zvarnykh dvotavriv zminnoho pererizu $z$ hnuchkoiu stinkoiu. [Experimental-theoretical methodology of calculation of steel frames made of welded joists of variable cross section with a flexible web]. Mistobuduvannia ta terytorialne planuvannia, no. 52, pp. 381-386. (in Ukrainian).

41. Timoshenko, S.P., Goodier, J.N. (1970). Theory of Elasticity: 3-rd ed. New York: McGraw-Hill Book Company.

42. Nadolskiy, V.V., Dergachev, M.G. (2017). Uchet sdvigovogo zapazdyvaniya soglasno trebovaniyam TKP EN 1993-1-5. [Consideration of shear lag due to demands of TKP EN 1993-1-5]. Proceedings of «Innovatsionnaya podgotovka inzhenernykh kadrov na osnove yevropeyskikh standartov (Evrokodov)», (Minsk, 30 may, 2017). Minsk: BNTU, pp. 109-117. (in Russian).

43. Kraus, M. (2017). Numerical approach for bending stress ascertainment in beam theory considering effects of elastic shear lag. Engineering Structures and Technologies, vol. 9, iss. 1, pp. 18 . 
44. Zhang, Y.H., Lin, L.X. (2014). Shear lag analysis of thin-walled box girders based on a new generalized displacement. Engineering Structures, vol. 61, pp. 73-83.

45. Mazinani, I., Jumaat, M.Z., Ismail, Z., Chao, O.Z. (2014). Comparison of shear lag in structural steel building with framed tube and braced tube. Structural Engineering and Mechanics, vol. 49, nо. 3, pp. 297-309.

46. Zhou, W.B., Jiang, L.Z., Liu, Z.J., Liu, X.J. (2012).Closed-form solution to thin-walled box girders considering effects of shear deformation and shear lag. Journal of Central South University, no. 19, pp. 2650-2655.

47. Zhang, Y.H. (2011). Improved finite-segment method for analyzing shear lag effect in thin-walled box girders. Journal of Structural Engineering, vol. 138, iss. 10, pp. 1279-1284.

48. Zhou, S.J. (2010). Finite beam element considering shear-lag effect in box girder. Journal of Engineering Mechanics, vol. 136, iss. 9, pp. 1115-1122.

49. Tahan, N., Pavlovic, M.N., Kotsovos, M.D. (1997). Shear-lag revisited: The use of single Fourier series for determining the effective breadth in plated structures. Computers \& structures, vol. 63, iss. 4, pp. 759-767.

50. Sedlacek, G., Bild, S. (1993). A simplified method for the determination of the effective width due to shear lag effects. Journal of Constructional Steel Research, vol. 24, iss. 3, pp. 155182.

51. Kristek, V., Studnicka, J. (1991). Negative shear lag in flanges of plated structures. Journal of structural engineering, vol. 117, iss. 12, pp. 3553-3569.

52. Shushkewich, K.W. Negative shear lag explained. (1991). Journal of structural engineering, vol. 117, iss. 11, pp. 3543-3546.

53. Papkovich, P.F. (1939). Teoriya uprugosti. [Theory of elasticity]. Moscow, Leningrad, Kyiv: Oborongiz. (in Russian).

54. Kirilenko, V.F. (2009). Primeneniye vidoizmenennogo resheniya Faylona $v$ prostranstvennykh raschetakh korobchatykh balok. [Application of the modified Filon's solution in volumetric calculations of box girders]. Zbirnyk naukovykh prats Ukrainskoho instytutu stalevykh konstruktsii imeni V. M. Shymanovskoho, no. 3, pp. 210-220. (in Russian).

55. Wang, H., Wang, Q., Qin, S. (2017). Effective Flange Width of Steel Box Girder Bridge According to British Specifications and Japanese Specifications. Proceedings of the 2017 3-rd International Forum on Energy, Environment Science and Materials (IFEESM 2017), Shenzhen, China, November 25-26, 2017. Atlantis Press, vol. 120, pp. 1364-1368. 
56. Yemelin, Y. (1992). On the effective width of girder flanges in elastic and elasto-plastic stages. Journal of Constructional Steel Research, vol. 21, iss. 1-3, pp. 195-204.

57. Szybinski, J., Ruta, P. (2019). Analysis of thin-walled beams with variable monosymmetric cross section by means of Legendre polynomials. Studia Geotechnica et Mechanica, vol. 41, iss. 1, pp. 1-12.

58. Ambrosini, D. (2009). On free vibration of nonsymmetrical thin-walled beams. Thin-Walled Structures, vol. 47, iss. 6-7, pp. 629-636.

59. Pagani, A., Carrera, E., Ferreira, A.J. M. (2016). Higher-order theories and radial basis functions applied to free vibration analysis of thin-walled beams. Mechanics of Advanced Materials and Structures, vol. 23, iss. 9, pp. 1080-1091.

60. Rybakov, V., Dyakov, S., Sovetnikov, D., Azarov, A., Ivanov, S. (2018). Finite elements apparatus in thin-walled rods dynamics problems. Proceedings of International Scientific Conference on Energy, Environmental and Construction Engineering (EECE2018), MATEC Web of Conferences, vol. 245, Article Number 08007, pp. 1-8.

61. Shen, Y., Zhu, Z., Wang, S., \& Wang, G. (2019). Dynamic analysis of tapered thin-walled beams using spectral finite element method. Shock and Vibration, vol. 2019, Article ID 2174209, pp. 1-13.

62. Mikhaylenko, T.G. (2013). O napryazhennom sostoyanii svarnykh uzlov stalnykh konstruktsiy. [About stress state of welded assemblies of steel constructions]. Tekhnicheskiye nauki - ot teorii $k$ praktike, no. 22, pp. 50-55. (in Russian).

63. Slipich, A.A., Movchan, I.A. (2012). Optimalnoye proyektirovaniye stalnykh balok dvutavrovogo secheniya. Visnyk Kryvorizkoho natsionalnoho universytetu, vol. 33, pp. 38-40. (in Russian).

64. Ozbasaran, H., Yilmaz, T. (2018). Shape optimization of tapered I-beams with lateral-torsional buckling, deflection and stress constraints. Journal of Constructional Steel Research, no. 143, pp. 119-130.

65. Mela, K., Heinisuo, M. (2014). Weight and cost optimization of welded high strength steel beams. Engineering structures, no. 79, pp. 354-364.

Стаття надійшла до редакиії 15.07.2020

Посилання на статтю: Соков В.М., Коростильов Л.І. Моделі та методи дослідження суднових балок зі зламом стінки та пояску // Вісник Одеського 


\begin{tabular}{c|c} 
ВІСНИК & HERALD \\
ОДЕСЬКОГО НАЦІОНАЛЬНОГО & OF THE ODESSA NATIONAL \\
МОРСЬКОГО УНІВЕРСИТЕТУ & MARITIME UNIVERSITY \\
№ $3(63), 2020$ & $№ 3(63), 2020$ \\
\hline
\end{tabular}

національного морського університету: 3б. наук. праць, 2020. № 3(63). C. 76-105. DOI 10.47049/2226-1893-2020-3-76-105.

Article received 15.07.2020

Reference a JournalArtic: Models and methods of analysis of ship beams with breaks of webs and girdle // Herald of the Odessa national maritime university. 2020. 3(63), 76-105. DOI 10.47049/2226-1893-2020-3-76-105. 